\title{
Peranan Orientasi Pasar dalam Meningkatkan Keunggulan Bersaing pada UMKM Lampu Gentur Cianjur
}

\author{
Adam Hakul Yakin*, Tintin Suhaeni \\ Jurusan Administrasi Niaga, Politeknik Negeri Bandung
}

\begin{abstract}
:
Gentur Lamp is one of the superior products of UMKM Cianjur Regency with poor development and experiencing problems in the decrease in production and decrease in turnover. The incapability of SMEs Gentur lights in fulfilling consumer desires and luster move in winning the market. The purpose ofWthis research isto find out how the implementation ofOmarket orientation conducted by SMEs Lampu Gentur Cianjur, how competitive advantage made by SMEs Lampu Gentur Cianjur, and how influence of market orientation to competitive advantage SMEs Lampu Gentur. This study used a sample of 109 MSMEs. The method used descriptive analysis with the results of market orientation included into the high category as well as competitive advantage belong to the high category. The result of Psimple linear regression analysis yielded the formula $Y=21,916+0,503 x$ with $R$ square equal to 0,344 which mean market orientation able to improving the competitiveness of SMEs Gentur Lamp with value 34,4\% and.the rest 65,4\% influenced'by]other factor.
\end{abstract}

Keywords: Competitive advantages, Market orientation, and SMEs Gentur Lamp Cianjur.

\section{Pendahuluan}

Di era globalisasi saat ini, dapat menjadi peluang besar bagi UMKM untuk mengembangkan usahanya. Terutama untuk produk-produk unggulan. Setiap kota atau daerah pada umumnya mempunyai produk khas atau unggulan yang mencirikan wilayahnya. Produk ini biasanya menjadi daya tarik dan buah tangan untuk para pengunjung yang datang di daerah itu. Produk khas itu diharapkan mampu memberikan keuntungan secara ekonomi untuk pemerintah dan masyarakat setempat. Untuk mendapatkan keuntungan itu, produk khas harus dikembangkan dan memiliki keunggulan kompetitif dengan menjadikan produk unggulan dalam kualitas, penampilan, bahan baku, teknologi, dan pemasaran yang baik.

Khususnya Cianjur, salah satu kabupaten di Provinsi Jawa Barat memiliki kekayaan akan budaya serta memiliki beberapa produk ciri khas yang sekarang menjadi produk unggulan. Salah satu produk unggulan di Kabupaten Cianjur yaitu Lampur Gentur. Lampu Gentur merupakan lampu hias yang berasal dari perjalanan sejarah leluhur kampung Gentur yang pertama kali membuat hasil karya ini. Lampu Gentur telah bertahan sejak tahun 1970 tetapi faktanya industri Lampu Gentur tidak mengalami perkembangan berdasarkan jumlah pelaku usaha yang tidak bertambah maupun berkurang.

Kondisi rata - rata produksi Lampu Gentur mengalami penurunan sebesar 18\% di tahun 2015 dan tahun 2016 sebesar 9\%. Penurunan produksi terjadi mulai dari tahun 2014 hingga 2016. Hal itu terjadi dikarenakan menurunnya penjualan dan tidak adanya pesanan dari pelanggan yang menyebabkan persediaan masih tersedia yang berdampak pada produksi yang menurun.

Rendahnya penjualan lampu gentur yang terjadi membuat perputaran produk (inventory turn over) rendah yang tidak mampu menutupi biaya produksi yang sangat tinggi. Ketidakmampuan para pelaku 
UMKM Lampu Gentur menekan biaya produksi membuat harga produk tinggi. Rata - rata inventory turn over lampu gentur yaitu sebesar 4 hari atau 78 kali per-tahun. Hal itu dimaksudkan bahwa UMKM Lampu Gentur harus mampu melakukan perputaran produk sebanyak 78 kali selama setahun atau singkatnya selama 4 hari. Tetapi nyatanya, mereka tidak mampu melakukan perputaran produk selama 4 hari karena rata - rata penjualan produk $2-3$ pcs selama seminggu dan produksi terjadi jika terjadi pesanan atau lampu yang di-display tersisa sedikit.

Berdasarkan hasil wawancara singkat kepada masyarakat lokal mengenai lampu gentur, ternyata produk dihasilkan berupa lampu hias yang unik menjadi sulit untuk mendapatkan perhatian konsumen, mereka sekarang lebih menginginkan dan menyukai bentuk lampu hias yang lebih modern atau lebih trendy. Selain itu, beberapa masyarakat lokal tidak mengetahui mengenai lampu gentur mulai dari bentuk hingga lokasi penjualannya. Perubahan trend yang terjadi di dalam masyarakat menyebabkan kebutuhan masyarakat berubah. Hal itu menjadi permasalahan untuk UMKM Lampu Gentur yang mengakibatkan ketidakmampuan UMKM Lampu Gentur dalam memenuhi keinginan konsumen yang berakibat penurunan dalam produksi lampu gentur dan penurunan omzet yang dialami selama tiga bulan terakhir.

Selain itu, UMKM Lampu Gentur tidak mampu bergerak cepat dalam menghadapi persaingan. Hal itu terlihat dari banyaknya pesaing - pesaing yang mampu menyediakan produk yang diinginkan oleh konsumen. Pesaing UMKM Lampu Gentur yaitu perusahaan distributor atau produsen yang menyediakan jenis - jenis lampu hias yang lebih modern dan trendy. Menurut para pelaku usaha UMKM Lampu Gentur, strategi yang digunakan dianggap kurang mampu mengalahkan pesaing karena produk yang dihasilkan kurang mampu bersaing dan kurangnya informasi mengenai pesaing tentang strategi yang dilakukan untuk mencapai target pasarnya.

Dalam konsep pemasaran, suatu perusahaan diharuskan mencari tahu mengenai kebutuhan pasar dan bagaimana memberikan kepuasan kepada pelanggan lebih dari pesaingnya. Perusahaan yang menerapkan konsep pemasaran semacam itu disebut perusahaan berorientasi pasar (Maruta et al., 2017).

Salah satu manfaat UMKM yang berorientasi pasar yaitu mampu meningkatkan keunggulan bersaing. Sebuah perusahaan yang berorientasi pasar akan mengetahui bagaimana cara memenuhi kebutuhan pelanggan, bagaimana strategi yang diterapkan mampu bersaing dengan pesaing, dan bagaimana sumber daya yang dimiliki mampu digunakan dengan tepat (Sørensen, 2009). Keunggulan bersaing merupakan strategi yang dirancang untuk menghadapi persaingan yang lebih efektif dan untuk mendominasi pasar (Porter dalam Maruta et al., 2017). Dalam pencapaian keunggulan bersaing, UMKM Lampu Gentur harus menciptakan customer value yang sama dengan pesaing dan lebih efisien dalam produksi atau menghasilkan nilai akhir serta harga yang kompetitif.

UMKM Lampu Gentur termasuk ke industri kreatif dimana produknya mengandalkan inovasi dan keunikan. Inovasi dan keunikan yang dihasilkan dari produk UMKM Lampu Gentur menjadi sumber daya yang mampu menciptakan nilai unggul dibanding para pesaingnya. Valuable, Rare, Imitable, dan Non-substitutable merupakan tolak ukur bagi perusahaan yang mempunyai sumber daya yang mampu menciptakan nilai unggul bagi perusahaannya (Barney, 1991).

Hasil penelitian Maruta et al. (2017) mengatakan bahwa terdapat pengaruh yang positifddan signifikan dari orientasi pasar terhadap keunggulan bersaing sebesar 37\%. Musigire (2016) dalam penelitiannya menyatakan hal yang serupa bahwa orientasi pasar mempengaruhi secara langsung terhadap keunggulan bersaing. Selain itu, terdapat penelitian yang mengatakan bahwa tidak semua dimensi orientasi pasar berpengaruh positif(dan signifikan terhadap keunggulan bersaing. Hal itu ditunjukkan oleh hasil penelitian dari Kaur dan Stanzin (2015) mengatakan bahwa hanya dimensi orientasi pesaing mempunyai pengaruh positif; dan signifikan terhadap keunggulan bersaing dibanding dimensi lainnya.

Berdasarkan uraian di atas dengan hasil beberapa penelitian sebelumnya dan fenomena yang terjadi, maka rumusan masalah dari penelitian ini adalah:

1. Bagaimana implementasi orientasi pasar yang dilakukan oleh UMKM Lampu Gentur Kabupaten Cianjur?

2. Bagaimana keunggulan bersaing yang dilakukan UMKM Lampu Gentur Kabupaten Cianjur?

3. Seberapa besar pengaruh orientasi pasar terhadap keunggulan bersaing UMKM Lampu Gentur Kabupaten Cianjur? 


\section{Kajian Literatur \\ Orientasi Pasar}

Orientasi pasar merupakan alat ukur perilaku dan aktivitas dari implementasi konsep pemasaran (Tjiptono dan Gregorius, 2012). Menurut Pelham (1997) berpendapat jika perusahaan yang berorientasi pasar merupakan perusahaan yang mampu mengembangkan dan memahami lebih baik mengenai apa yang dibutuhkan konsumen sehingga dapat menciptakan customer value dan menciptakan strategi pasar dengan informasi kekuatan serta kelemahan pesaing. Narver dan Slater (1990) mengatakan bahwa orientasi pasar merupakan budaya organisasi yang dimana menempatkan prioritas tertinggi pada superior customer value. Sedangkan Craven dan Piecry (2013) Orientasi pasar merupakan suatu perspektif yang menempatkan konsumen sebagai fokus perhatian dalam kegiatan perusahaan. Berdasarkan pendapat diatas, dapat disimpulkan bahwa orientasi pasar merupakan suatu tindakan yang harus dilakukan oleh perusahaan untuk menciptakan superior customer value dengan cara menjadikan konsumen menjadi pusat perhatian perusahaan.

Di dalam orientasi pasar, Narver dan Slater (1990) mengatakan bahwa terdapat tiga dimensi yaitu orientasi pelanggan, orientasi pesaing, orientasi antar fungsi. Dimensi pertama yaitu orientasi pelanggan. Orientasi pelanggan yaitu Pemahaman yang memandai atas pelanggan agar mampu menciptakan nilai superior bagi perusahaan secara berkesinambungan. Perusahaan yang berorientasi pada pelanggan akan berupaya menggali sumber daya yang dimiliki untuk membuat produk yang terbaik. Perusahaan memiliki peluang untuk membentuk persepsi pelanggan atas nilai - nilai yang dibangunnya dan nilai - nilai yang dirasakan itu akan menghasilkan nilai kepuasan pelanggan. Hasil akhir dari orientasi pelanggan ini merupakan membuat pelanggan puas dan loyal.

Dimensi kedua yaitu orientasi pesaing. Orientasi pesaing adalah perusahaan memahami keunggulan dan kelemahan serta kapabilitas juga strategi jangka panjang maupun jangka pendek para pesaing saat ini dan pesaing potensial. Perusahaan berorientasi pada pesaing akan menggunakan sebagian waktunya untuk mencari tahu strategi dan pangsa pasar pesaingnya serta berusaha menemukan strategi untuk melawannya (Sandvik, 2003).

Dimensi terakhir yaitu orientasi antar fungsi. Orientasi antar fungsi adalah pemanfaatan sumber daya perusahaan secara terkoordinasi dalam menciptakan nilai superior bagi para pelanggan. Koordinasi antar fungsi di dalam perusahaan harus diarahkan untuk memenuhi kebutuhan pelanggan dengan memberikan nilai terbaik dibanding pesaingnya sehingga terciptanya kepuasan bagi pelanggan. Koordinasi antar fungsi dapat diartikan sebagai kemampuan yang dibutuhkan oleh perusahaan dalam rangka membentuk rantai nilai yang meliputi aktivitas utama dan aktivitas pendukung (Zhou et al., 2009). Kemampuan khusus harus dimiliki perusahaan dalam mengintegrasikan tugas individu kedalam fungsi yang lebih luas cakupannya seperti kemampuan pemasaran, riset, dan pengembangan (Dewi, 2006). Integrasi antar fungsi dalam perusahaan memerlukan sumber daya khususnya pengetahuan dan keahlian dari setiap pekerja sehingga dapat mendukung organisasi dalam menyajikan nilai terbaik untuk pelanggan.

\section{Keunggulan Bersaing}

Perusahaan memerlukan suatu strategi yang memiliki keunggulan dibanding pesaingnya. Salah satu strategi yang sering digunakan yaitu keunggulan bersaing. Keunggulan bersaing akan tercapai jika pelanggan mampu membedakan produk dan fasilitas yang diberikan oleh perusahaan dibanding persaing serta perusahaan mampu memberikan apa yang diinginkan oleh pelanggan dengan hal yang sulit untuk diikuti oleh pesaingnya.

Keunggulan bersaing mempunyai dua sumber yang berbeda tetapi saling melengkapi. Pertama, keunggulan berasal dari sumber daya dan keahlian yang dimiliki oleh perusahaan yang dapat dijadikan sebagai keunggalan dibanding pesaing. Kedua, keunggulan berasal dari posisi perusahaan sekarang yang dibandingkan dengan pesaingnya. Posisi itu dapat berasal dari bagaimana citra pelanggan di mata pelanggannya (Bharadwaj et al., 1993)

Untuk mencapai keunggulan bersaing, perusahaan harus menciptakan customer value yang sama dari pesaing dan lebih efisien dalam produksi atau menghasilkan nilai akhir dan harga yang berbeda (Passemard dan Kleiner, 2000). Dalam pencapaian keuntungan berbisnis, perusahaan harus mampu melihat apa yang dimiliki, apa yang diketahui dan lakukan, dan apa yang diperoleh. 
menurut Barney (1991) mengatakan bahwa keunggulan dapat dicapai jika perusahaan mempunyai sumber daya dan juga mampu menciptakan nilai unggul bagi perusahaannya. Hal itu dapat diukur dengan Valuable, Rare, Imitable, dan Non- substitutable. Valuable berfokus kepada menciptakan nilai bagi perusahaan dalam mencari peluang dan meminimalisir ancaman dengan sumber daya yang dimiliki. Rare berfokus kepada sumber daya dan produk yang dihasilkan langka atau unik sehingga menjadi potensi perusahaan. Imitable berfokus pada sumber daya dan produk yang tidak mudah ditiru oleh pesaingnya. Non- substitutable merupakan sumber daya yang tidak dapat sulit untuk digantikan dengan alternatif lainnya.

\section{Hubungan Orientasi Pasar dengan Keunggulan Bersaing}

Orientasi pasar dapat memiliki peran penting dalam memprediksi keunggulan bersaing (Musigire, 2016). Hal itu dikarenakan setiap harinya persaingan semakin ketat di dalam industri. Jika perusahaan tidak mampu bertahan dengan memenuhi kebutuhan dan keinginan pelanggan, perusahaan akan gulung tikar atau perusahaan tersebut tidak mampu untuk memenangkan persaingan. Orientasi pasar akan menciptakan customer value yang lebih baik yang akhirnya akan membawa pada keunggulan bersaing (Flint et al, 1997). Orientasi pasar dapat membantu perusahaan dalam menyadari kebutuhan pelanggan dan strategi pesaing serta membuat para karyawan termotivasi untuk memberikan superior customer satisfaction (Pelham, 1997). Orientasi pasar dapat digunakan dalam membangun keunggulan bersaing yang kuat jika perusahaan mampu menyediakan informasi yang relevan dan diterapkan dengan benar sebagai bagian dari strategi.

Orientasi pasar akan menghasilkan informasi mengenai pelanggan dan pesaing serta dalam penyebaran informasi ke seluruh organisasi dan dapat bekerja sama antar departemen dalam organisasi untuk menciptakan dan memberikan customer value. Sehingga orientasi merupakan sumber keunggulan bersaing yang berharga (Ge dan Daniel, 2005). Perusahaan yang menggunakan orientasi pasar akan memiliki kelebihan mengenai informasi pelanggan dan menjadi sumber terciptanya produk yang diinginkan serta dibutuhkan pelanggan.

Orientasi pasar dapat mengidentifikasi kebutuhan pelanggan sehingga perusahaan diharapkan mampu menyediakan apa yang dibutuhkan melalui penciptaan produk baru atau pengembangan produk untuk memenangkan persaingan (Li dan Zhou, 2010).

Sementara itu, orientasi pasar dapat menjadi respon terhadap keinginan dan kebutuhan pasar (Jaworski dan Kohli, 1993). Perusahaan akan terus memfasilitasi dalam pengembangan strategi secara fokus dalam pencapaian keunggulan kompetitif dengan memenuhi keinginan dan kebutuhan pelanggan. Untuk dapat menjadi pemenang di dalam persaingan yang kompleks perusahaan harus mampu membuat strategi yang berorientasi pada proses manajerial dalam mengembangkan dan mempertahankan kesesuaian antara tujuan, kemampuan, dan perubahan pada pasar (Kotler dan Amstrong, 2012).

Di bawah ini merupakan kerangka pemikiran penelitian yaitu sebagai berikut:

$\begin{array}{cc}\text { Orientasi Pasar (X) } & \begin{array}{c}\text { Keunggulan } \\ \text { Bersaing (Y) }\end{array} \\ \begin{array}{c}\text { Orientasi pelanggan } \\ \text { Orientasi pesaing } \\ \text { Orientasi antar fungsi }\end{array} & \rightarrow \quad \begin{array}{c}\text { Valuable Rare } \\ \text { Imitable } \\ \text { Non-Subtitutable }\end{array} \\ \begin{array}{c}\text { Narver dan Slater (1990); } \\ \text { Deshpande } \text { et al., (1993); } \\ \text { Maruta } \text { et al,. (2017) }\end{array} & \begin{array}{c}\text { Barney (1991); } \\ \text { Cardeal (2012); }\end{array} \\ & \text { Priem dan Butler (2001). }\end{array}$

\section{Gambar 1 Kerangka Pemikiran}

Berdasarkan kerangka pemikiran di atas, maka dapat dirumuskan hipotesis sebagai berikut:

Ho : Tidak adanya pengaruh Orientasi pasar terhadap keunggulan bersaing UMKM Lampu Gentur Kabupaten Cianjur. 
H1 : Adanya pengaruh Orientasi pasar terhadap keunggulan bersaing UMKM Lampu Gentur Kabupaten Cianjur.

\section{Metode Penelitian}

Dalam penelitian ini, peneliti menggunakan metode deskriptif. Menurut Sugiyono (2013) berpendapat bahwa metode deskriptif merupakan metode penelitian yang bertujuan untuk mengetahui nilai dari antar variabel tanpa membuat perbandingan atau menghubungkan satu sama lainnya. Penelitian deskriptif bertujuan untuk memperoleh deskriptif mengenai orientasi pasar yang terdiri dari orientasi pelanggan, orientasi pesaing, dan koordinasi antar fungsi serta bagaimana keunggulan bersaing UMKM Lampu Gentur Kabupaten Cianjur.

Populasi dalam penelitian ini adalah seluruh UMKM Lampu Gentur Kabupaten Cianjur yang berjumlah 109 unit usaha. Dalam penelitian ini, penulis menggunakan teknik penarikan sampling dengan Sensus Sehingga, sampel yang diambil dalam penelitian ini yaitu sebanyak populasi sebesar 109 unit usaha dengan responden pemilik usaha. Sedangkan teknik pengambilan data menggunakan dua teknik yaitu kuesioner dan studi pustaka.

Kuesioner dalam penelitian ini menggunakan skala likert dengan penelitian 1-5. Uji validitas dan reliabilitas sudah dilakukan dengan hasil semua pernyataan dikatakn validitas dan reliabilitas karena hasil Corrected item-total correlation $\geq 0,30$ dan Cronbach's Alpha $\geq 0,60$. Analisis yang digunakan dengan menggunakan uji asumsi klasik (Uji Normalitas, linearitas, dan heterokedastisitas), analisis deksriptif, analisis regresi linier sederhana, koefisien determinasi, dan uji hipotesis (Uji F dan Uji t).

\section{Hasil dan Pembahasan}

Analisis deskriptif orientasi pasar ini dilakukan untuk menjawab identifikasi masalah yang pertama dalam penelitian ini yaitu bagaimana implementasi orientasi pasar yang dilakukan oleh UMKM Lampu Gentur. Terlihat dari tabel 1, orientasi pasar yang sudah diimplementasikan sudah baik. Dari ketiga dimensi, orientasi pelanggan merupakan dimensi terendah sehingga dapat diindikasikan bahwa pelaku usaha UMKM lampu gentur masih belum mengoptimalkan dalam pemusatan terhadap orientasi pelanggan seperti ketidakmampuan dalam mencari mengenai targer pasar. Disisi lain, dimensi lainnya termasuk dalam kategori tinggi. Sehingga dapat diindikasikan bahwa pelaku usaha lampu gentur mengimplementasikan orientasi pesaing dan orientasi antar fungsi dalam penerapan orientasi pasarnya.

Tabel 1 Nilai Rata-Rata Orientasi Pasar

\begin{tabular}{|c|c|}
\hline Keterangan & Mean \\
\hline Orientasi Pelanggan & 3,2055 \\
\hline Orientasi Pesaing & 3,6468 \\
\hline Orientasi Antar Fungsi & 3,9156 \\
\hline Orientasi Pasar & $\mathbf{3 , 5 8 9 3}$ \\
\hline
\end{tabular}

Analisis deskriptif keunggulan bersaing ini dilakukan untuk menjawab dengan jelas mengenai identifikasi masalah yang kedua dalam penelitian ini yaitu bagaimana keunggulan bersaing yang dilakukan oleh UMKM Lampu Gentur. Terlihat dari tabel 2, semua dimensi keunggulan bersaing termasuk kedalam kategori tinggi. Sehingga hal ini mengindikasikan bahwa kemampuan pelaku usaha UMKM lampu gentur dalam mengelola sumber daya menjadi keunggulan bersaing sudah optimal dibandingkan dengan para pesaing dalam menghadapi dinamika pesaing.

Tabel 2 Nilai Rata-Rata Keunggulan Bersaing

\begin{tabular}{|c|c|}
\hline Keterangan & Mean \\
\hline Valueable & 3,7492 \\
\hline Rare & 3,8012 \\
\hline Imitable & 3,9702 \\
\hline Non-Subtitutable & 3,9679 \\
\hline Keunggulan Bersaing & $\mathbf{3 , 9 0 1 8}$ \\
\hline
\end{tabular}




\section{Analisis Korelasi}

Berdasarkan tabel 3, dapat terlihat bahwa nilai korelasi dari kedua variabel ini yaitu sebesar 0,586 yang berada pada rentang nilai 0,40-0,599. Hal itu berarti hubungan antara orientasi pasar dan keunggulan bersaing memiliki hubungan yang positif dan sedang.

Selain itu, nilai korelasi yang terdapat dalam tabel diatas dapat menunjukkan bahwa hubungan yang terjadi yaitu searah dikarenakan hubungan yang terjadi merupakan hubungan positif. Hal itu dapat berarti bahwa jika orientasi pasar meningkat maka akan diikuti oleh peningkatan keunggulan bersaing. Selain itu, nilai signifikan yaitu 0,000 . Sugiaman (2008), jika nilai sig $<0,05$ maka korelasi signifikan dan jika nilai sig $>0,05$ maka korelasi tidak signifikan. Sehingga dapat disimpulkan bahwa nilai korelasi penelitian ini memiliki hubungan yang signifikan.

Tabel 3 Hasil Analisis Korelasi

\begin{tabular}{|c|c|c|c|}
\hline & & Orientasi Pasar & Keunggulan Bersaing \\
\hline \multirow[t]{3}{*}{ Orientasi Pasar } & $\begin{array}{l}\text { Pearson } \\
\text { Correlation }\end{array}$ & 1 &, $586^{* *}$ \\
\hline & $\begin{array}{l}\text { Sig. (2- } \\
\text { tailed) }\end{array}$ & &, 000 \\
\hline & $\mathrm{N}$ & 109 & 109 \\
\hline \multirow[t]{3}{*}{ Keunggulan Bersaing } & $\begin{array}{l}\text { Pearson } \\
\text { Correlation }\end{array}$ &, $586^{* *}$ & 1 \\
\hline & $\begin{array}{l}\text { Sig. (2- } \\
\text { tailed) }\end{array}$ &, 000 & \\
\hline & $\mathrm{N}$ & 109 & 109 \\
\hline
\end{tabular}

\section{Analisis Regresi Linier Sederhana}

Berdasarkan tabel 4, dapat diketahui bahwa nilai konstanta (a) sebesar 21,916 dengan koefisien (b) sebesar 0,503. Sehingga dari informasi itu, dapat ditentukan persamaan regresi penelitian ini yaitu sebagai berikut:

$\mathrm{Y}=\mathrm{a}+\mathrm{bx}$

$\mathrm{Y}=21,916+0,503 \mathrm{x}$

Dari persamaan diatas, dapat disimpulkan bahwa sebesar nilai konstanta sebesar 21,916 memiliki arti yaitu jika orientasi pasar tidak mengalami kenaikan atau penurunan $(X=0)$ maka keunggulan bersaing akan tercapai sebesar 21,916. Selain itu, terdapat nilai koefisien regresi linier sebesar 0,503 yang berarti bahwa setiap penambahan satu angka orientasi pasar dengan koefisien positif maka keunggulan bersaing akan meningkat sebesar 0,503.

Berdasarkan tabel 5, dapat disimpulkan bahwa hasil koefisiensi determinasi (R Square) yaitu sebesar 0,344 atau $34,4 \%$. Sehingga orientasi pasar mampu mempengaruhi keunggulan bersaing UMKM Lampu Gentur sebesar 34,4\% dan sisanya 65,6\% dipengaruhi oleh faktor lainnya yang tidak dijelaskan didalam penelitian ini.

Tabel 5 Analisis Koefisien Determinasi

\begin{tabular}{|l|l|l|l|l|}
\hline Model & R & R Square & Adjusted R Square & Std. Error of the Estimate \\
\hline 1 &, $586 \mathrm{a}$ &, 344 &, 338 & 5,10163 \\
\hline
\end{tabular}

\section{Pengaruh Orientasi Pasar Terhadap Keunggulan Bersaing}

Penelitian ini dilakukan kepada 109 responden yang merupakan pemilik dari UMKM Lampu Gentur Kabupaten Cianjur. berdasarkan hasil analisis korelasi, diperoleh hasil yang menunjukkan terdapat hubungan yang positif dan signifikan dari kedua variabel orientasi pasar dan keunggulan bersaing. Hal ini ditunjukkan dengan hasil sebesar 0,586.

Didalam analisis regresi yang dilakukan dalam penelitian ini, orientasi pasar mempunyai pengaruh positif terhadap keunggulan bersaing. Hal itu dapat dilihat dari persamaan regresi linier sederhana yaitu $\mathrm{Y}=21,916+0,503 \mathrm{x}$. Nilai konstanta sebesar 21,916 dan koefisien regresi sebesar 0,503 yang mempunyai arti setiap adanya pertambahan satu angka terhadap orientasi pasar akan meningkatkan pula 
nilai keunggulan bersaing. Sementara itu, hasil dari koefisien determinasi dapat terlihat bahwa orientasi pasar mempunyai pengaruh sebesar 34,4\% terhadap keunggulan bersang dan sisanya 65,6\% dipengaruhi oleh faktor lainnya yang tidak dijelaskan didalam penelitian ini.

Penelitian Dalimunthe (2017), orientasi pasar berpengaruh secara signifikan terhadap keunggulan bersaing namun terdapat perbedaan yaitu persentase dari pengaruh yang ditimbulkan lebih kecil dibanding penelitian ini sebesar $34,4 \%$. Sementara itu, uji statistik F menghasilkan nilai $\mathrm{F}$ hitung sebesar 56,058 dan untuk nilai $\mathrm{F}$ tabel diketahui sebesar 3,93 dengan nilai signifikansi yang dihasilkan sebesar 0,000. Hal itu dapat menunjukkan bahwa nilai $\mathrm{F}$ hitung lebih besar dibanding $\mathrm{F}$ tabel dengan signifikansi yang kurang dari 0,05 sehingga dapat Ho ditolak dan $\mathrm{H} 1$ diterima. Hasil itu dapat menunjukkan bahwa terdapat pengaruh yang signifikan dari orientasi pasar terhadap keunggulan bersaing. Selain itu, dari hasil uji statistik t menghasilkan nilai t hitung sebesar 7,487 dan nilai tabel yaitu sebesar 1.65909 dengan nilai probabilitas sebesar 0,000 sehingga dapat diambil kesimpulan bahwa terdapat pengaruh positif dan signifikan dari orientasi pasar terhadap keunggulan bersaing. Hal itu dikarenakan nilai t hitung yang lebih besar dari t tabel dan nilai signifikansi atau probabilitas yang kurang dari 0,05 sehingga Ho ditolak dan H1 diterima. Dengan demikian, model regresi dapat digunakan untuk memprediksi keunggulan bersaing UMKM Lampu Gentur Kabupaten Cianjur.

\section{Kesimpulan dan Saran \\ Kesimpulan}

Implementasi orientasi pasar yang dilakukan oleh UMKM Lampu Gentur Kabupaten Cianjur sudah baik. Hal itu terlihat dari ketiga dimensi, orientasi pelanggan merupakan dimensi terendah dalam kategori cukup sedangkan dimensi orientasi pelanggan dan orientasi antar fungsi dalam kategori tinggi. Keunggulan bersaing pada UMKM Lampu Gentur Kabupaten Cianjur sudah baik, yang diuji dengan 4 dimensi yaitu valuable, rare, imitable, dan non-subtitutable. Dimensi imitable merupakan dimensi tertinggi dibanding yang lainnya dan dimensi terendah yaitu valuable. Terdapat hubungan yang positif serta signifikan antara orientasi pasar dengan keunggulan bersaing. Selain itu, orientasi pasar mampu meningkatkan sebesar 34,4\% keunggulan bersaing.

Berdasarkan kesimpulan yang telah dibahas diatas, terdapat saran dengan maksud memberikan masukan yang positif berhubungan dengan pengaruh orientasi pasar terhadap keunggulan bersaing. Dimensi terendah dalam orientasi pasar yaitu orientasi pelanggan. Untuk itu, pelaku usaha UMKM Lampu Gentur harus lebih fokus terhadap pelanggan. Hal itu dapat dilakukan seperti meluangkan waktu lebih untuk mencari informasi mengenai pelanggan dengan cara mengikuti bazar ataupun pameran. Untuk lebih mendekatkan diri dengan konsumen, sebaiknya pelaku usaha menjual produk melalui web atau sosial media serta membuat billboard jalan yang dipasang sebagai dengan tulisan "Sentral UMKM Lampu Gentur" untuk memudahkan masyarakat mengetahui lokasi lampu gentur. Dimensi terendah dalam keunggulan bersaing yaitu valuable. Sebaiknya, pelaku usaha melakukan pengembangan tidak hanya ketika terdapat pesanan melainkan menambah bentuk atau design yang lebih baru dan inovasi untuk di pajak di dalam tokonya. Sehingga diperlukan pelatihan terhadap para karyawannya ataupun mengikuti seminar-seminar yang diadakan oleh PLUIT KUMKM sehingga pemilik usaha lebih terbuka mengenai kreativitas untuk produk lampunya. Untuk penelitian selanjutnya, diharapkan dapat membahas tentang branding, kemampuan manajemen, modal kerja, dan loyalitas pelanggan.

\section{Daftar Pustaka}

Barney, Jay B. 1991. "Firm Resources and Sustained Competitive Advantage." Journal of Management 17(1):99-120.

Bharadwaj, Sundar G., P. Rajan Varadarajan, and John Fahy. 1993. "Competitive Advantage in Service Industries : A Conceptual Model.” Journal of Marketing 57(4):83-99.

Cardeal, Nuno. 2012. "Valuable, Rare, Inimitable Resources and Organization (VRIO) Resources or Valuable, Rare, Inimitable Resources (VRI) Capabilities: What Leads to Competitive Advantage?" African Journal of Business Management 6(37).

Craven, David W. and Nigel F. Piecry. 2013. Strategic Marketing. 10th ed. New York: McGraw-Hill International Edition.

Dalimunthe, Muhammad Bukhori. 2017. "Keunggulan Bersaing Melalui Orientasi Pasar Dan Inovasi Produk.” Jurnal Konsep Bisnis Dan Manajemen 2(1):18-31. 
Deshpande, Rohit, John U. Farley, and Frederick E. Webster. 1993. "Corporate Culture, Customer Orientation, and Innovativeness in Japanese Firms: A Quadrad Analysis." Journal of Marketing 57(1):23.

Flint, Daniel J., Robert B. Woodruff, and Sarah Fisher Gardial. 1997. "Customer Value Change in Industrial Marketing Relationships: A Call for New Strategies and Research." Industrial Marketing Management 26(2):163-75.

Ge, Gloria L. and Z. Din. Daniel. 2005. "Market Orientation, Competitive Strategy and Firm Performance: An Empirical Study of Chinese Firms." Journal of Global Marketing 18(34):115-42.

Jaworski, Bernard J. and Ajay K. Kohli. 1993. "Market Orientation: Antecedents and Consequences." Journal of Marketing 57:53-70.

Kaur, Gurjeet and Mantok Stanzin. 2015. "Role of Market Orientation and Competitive Advantage in Firm ' S Performance." International Journal of Applied Business and Economic Research 13(3):1229-41.

Kotler, Philip and Gay Amstrong. 2012. Prinsip - Prinsip Pemasaran Jilid 1. 3rd ed. Jakarta: Erlangga.

Li, Julie Juan and Kevin Zheng Zhou. 2010. "How Foreign Firms Achieve Competitive Advantage in the Chinese Emerging Economy: Managerial Ties and Market Orientation." Journal of Business Research 63(8):856-62.

Maruta, I. G. N. Anom, Sularso Andi, and Susanti Nanis. 2017. "The Effect of Market Orientation, Entrepreneurship Orientation, and Imitation Strategy on Competitive Advantage ( Study on SME of Leather Bag and Suitcase in East Java

)." International Journal of Business and Management Invention 6(7):24-35.

Musigire, Samuel. 2016. "Market Orientation and Competitive Advantage: Mediating Role of Strategic Ambidexterity." ORSEA Journal 6(1):190-219.

Narver, John C. and Stanley F. Slater. 1990. "The Effect of a Market Orientation on Business Profitability." Journal of Marketing 54(4):20.

Passemard, D. and Brian H. Kleiner. 2000. "Competitive Advantage in Global Industries." Management Research News 23(7/8):111-17.

Pelham, a M. 1997. "Market Orientation and Performance: The Moderating Effects of Product and Customer Differentiation." Journal of Business \& Industrial Marketing 12(5):276-96.

Priem, Richard L. and John E. Butler. 2001. "Is the Resource-Based for Strategic Management Perspective Research?" Academy of Management Review 26(1):22-40.

Sandvik, Izabela Leskiewicz. 2003. "The Impact of Market Orientation on Product Innovativeness and Business Performance." Intern. J. of Research in Marketing 20:355-376.

Sørensen, Hans Eibe. 2009. "Why Competitors Matter for Market Orientation." European Journal of Marketing 43(5/6):735-61.

Sugiyono. 2013. Metode Penelitian Kuantitatif Kualitatif Dan R\&D. Bandung: Alfabeta.

Tjiptono, Fandy and Chandra Gregorius. 2012. Pemasaran Strategik. 2nd ed. Yogyakarta: ANDI.

Zhou, Kevin Zheng, R. Brown James, and S. Dev Chekitan. 2009. "Market Orientation, Competitive Advantage, and Performance: A Demand-Based Perspective." Journal of Business Research 62(11):1063-70.

\section{*Email korespondensi:}

Adam Hakul Yakin

adamhakulyakin@yahoo.com 